\title{
Water Allocation and Integrative Management of Precision Irrigation: A Systematic Review
}

\author{
Zhongwei Liang ${ }^{1,2, * \mathbb{D}}$, Xiaochu Liu ${ }^{1,2}$, Jianbin Xiong ${ }^{3}$ and Jinrui Xiao ${ }^{1,2}$ \\ 1 School of Mechanical and Electrical Engineering, Guangzhou University, Guangzhou 510006, China; \\ xiaochuliu1964@126.com (X.L.); jinruixiaogzhu@126.com (J.X.) \\ 2 Guangdong Engineering Research Centre for High Efficient Utility of Water/Fertilizers and Solar Intelligent \\ Irrigation, Guangzhou University, Guangzhou 510006, China \\ 3 School of Automation Engineering, Guangdong Polytechnic Normal University, Guangzhou 510665, China; \\ gzbhxie@yeah.net \\ * Correspondence: liangzhongwei@gzhu.edu.cn
}

Received: 7 September 2020; Accepted: 5 November 2020; Published: 9 November 2020

check for updates

\begin{abstract}
Precision irrigation, defined as an efficient water allocation technique characterized by the optimal management and best collaboration of various factors of the irrigation process, attracts considerable attention in agricultural production and crop cultivation. This paper reviews the latest research developments in water allocation mechanism and integrative management effectiveness of precision irrigation, and highlights how irrigation water allocation and integrative management contribute to the high-efficiency performance of precision irrigation techniques; the irrigation models, irrigation infrastructure, and management strategies currently being used are emphasized. Thereafter, the future development prospects in water allocation and integrative management could be systematically analyzed and subsequently explored. Some frontier techniques such as data-oriented irrigation management, performance-proven water allocation, and cloud-based irrigation control are among the critical technologies capable of building a sustainable, integrative, and evolutionary irrigation system while providing the higher quality and efficiency needed for a full application of precision irrigation. This review could be used as an effective reference to study the complicated correlations between precision irrigation and its constructive influences in different environmental conditions, and to facilitate the practical promotion of irrigation productivity with higher accuracy and increased reliability of returns.
\end{abstract}

Keywords: precision irrigation; water allocation; mechanism; integrative management; effectiveness

\section{Introduction}

Precision irrigation can be defined as an efficient collaboration and precise application of water to meet specific requirements of individual plants or management units and minimize related adverse environmental impacts. As a holistic coordinated performance, precision irrigation not only enables the emergence of more flexible and reactive operational systems, but also involves the optimal management and best operation of agricultural irrigation systems; therefore, it has been employed in response to the growing problem of water scarcity and the need for more effective irrigation management. Precision irrigation comprises a wide range of participant component systems, both at on-farm plot and scheme levels, corresponding to different management and monitoring realities, and having the potential to be applied as an effective water-allocation support tool for cropping patterns in an irrigated area and irrigation scheduling [1]. Direct benefits of the water allocation mechanism and integrative management effectiveness of precision irrigation are expected in the following. 
(1) Irrigation collaboration. Advanced design methods and optimization tools of irrigation equipment enable the development of water allocation with both physical and virtual prototyping for the optimum collaboration of irrigation systems, which are capable of representing spatial and temporal water allocation variations within the agricultural field at a compatible resolution with farming management activities [2].

(2) Water resource supply. Water resources immediately transmitted to the whole supply chain of precision irrigation enable a constant synchronization between advanced water allocation control and mechanism adaptation to unforeseen environmental changes, giving farmers higher precision and flexibility in water allocation and scheduling implementation in practice.

(3) Irrigation implementation. Using stage irrigation objectives as elements of water allocation allows instantaneous collection of data about influential factors related to the agricultural production system [3]. It is possible to adjust the corroborative behavior of the irrigation system under unusual cultivation conditions or environmental condition changes, which helps to determine the optimal timing of irrigation when planning water allocation schemes.

This article provides a throughout overview of the research developments in water allocation mechanism and integrative management effectiveness, and explains how they contribute to the sustainability and stability of irrigated agriculture. In the past several years, the water allocation mechanism of precision irrigation makes remarkable contributions to the appropriate redistribution of water resources in the irrigated soil. Moreover, the integrative management effectiveness in irrigation practices becomes a decisive benchmark for accurate calibration of irrigated agriculture, especially in typical application cases such as moisture infiltration measurement, adaptive irrigation scheduling, and dynamic groundwater distribution. However, it is regretful that such important topics have rarely been focused on and discussed before, even if no previous research has provided such an important and flashed out the review on water allocation mechanism and integrative management effectiveness, which presents a major obstacle to the increase of irrigation efficiency and promotion of irrigation techniques during agricultural crop production. Therefore, it is an urgent need to propose a comprehensive review of these key topics to demonstrate their uniqueness and originality for precision irrigation. According to this conditional requirement, firstly, a systematic overview focusing on the water allocation mechanism is presented, followed by a set of concentrated comparisons of the performance properties of water allocation techniques in regards to the factors influencing irrigation environment; secondly, the integrative management effectiveness of precision irrigation is outlined; thirdly, with the future development prospects of precision irrigation being discussed, this paper makes conclusion eventually.

\section{Water Allocation Mechanism of Precision Irrigation}

High-efficient water allocation mechanism can be defined as the accurate and efficient distribution strategies of water resources to increase agricultural productivity and increase crop yield in practical irrigation applications. Appropriate irrigation water allocation can reduce water losses, overcome topographic constraints, avoid uncontrolled water/soil withdrawals, and be used to accurately measure the exact amount of water consumed [4].

As shown in Figure 1, the research progress and equipment developments in the water allocation mechanism produced significant advantages including higher water use efficiency (WUE), lower energy requirements, higher field yields, and better quality of harvested crops. Environmental maintenance and resource recyclings are necessary irrigation parametric coefficients or influential process factors, that lead to the environment-oriented water allocation monitoring and information management abilities to attain environmental maintenance and resource recycling. The water allocation mechanism facilitates the soil/water balance, and determines optimal irrigation schedule and cropping pattern in irrigated agriculture. Given a large amount of generic and pervasive research on this topic, three major problems arise. 
(1) Determining how to build a generic and effective water allocation scheme that enables the increase of WUE and acceleration of moisture infiltration in field soil for their performance benchmarking. The inner architecture and inherent principles of water allocation mechanism should be investigated further to standardize and facilitate their wide application, which appears to be currently important.

(2) Determining the optimal method to integrate the necessary elements of water allocation in a given precision irrigation system. As irrigation efficiency should be monitored closely and enhanced significantly, the schedule principle and control architecture in water allocation need to be simultaneously synchronized. The instantaneous investigation of irrigation turn duration, based on the coordinated behavior of the water allocation system or the adaptive control of moisture infiltration, makes the task more challenging as it requires the water resource allocation responsible for the irrigation scenario management to be omniscient.

(3) Defining a full set of water allocation scenarios that are representative of the diversity of irrigation requirements encountered and resource allocation objectives expected. Currently, the applicable research on this topic is still too limited and the studies do not cover the whole scope of the water allocation mechanism.

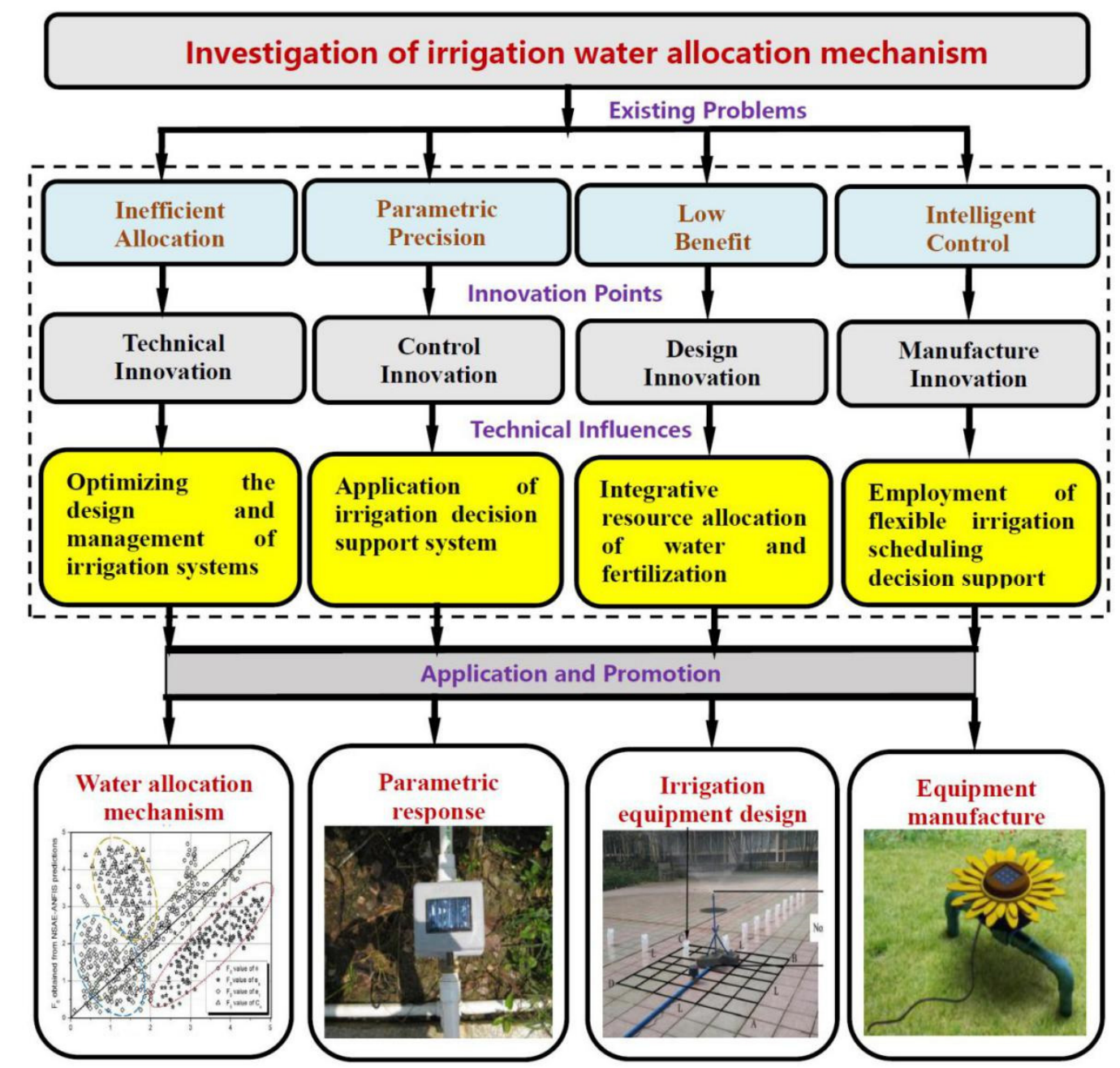

Figure 1. Research progress and equipment development in the water allocation mechanism.

As defined in the water research literature, the technical adaptivity of precision irrigation is the capacity of the water allocation system to collaboratively work with other facility parts, which is 
related to the physical connections of different components in irrigation systems. Considering the adaptivity, as the efficiency and uniformity of precision irrigation can be maintained from the complex and diverse schedule-based systems by considering weather, soil, water, and crop data, a decision support system (DSS) model was designed to acquire real-time water/soil and environmental data using a wireless sensor network [5,6]. Motivated by this technological tendency, a radial basis function type of neural network was used to predict the hourly requirement of soil moisture content (MC) as well as the required soil evapotranspiration using the Penman-Monteith method or the Food and Agriculture Organization (FAO) model. Similarly, a fuzzy-logic-based weather-dependent irrigation control mechanism was developed and integrated with an interoperable decision support system (DSS) to generate adequate water allocation notifications by interfacing with Global System for Mobile communications (GSM) modem. Some researches [7-9] indicated that precision irrigation performance could be determined using the amount of supplied water, water delivery infrastructure, use of groundwater, water allocation method, infrastructure size, and the price paid for irrigation resource consumption. Therefore, the practical irrigation systems with high energy demands should only be used when they permit reductions in the irregularity of water supply and shortage of risks in water resource allocation.

To quantify the constructive influence of indoor water allocation mechanism on crop productivity and grain yield, a greenhouse irrigation experiment conducted revealed that thin shallow moist dry irrigation (TSMDI) had significantly higher water productivity [10], and the irrigation water consumption could be reduced remarkably, indicating that local data information on root growth patterns is crucial to understanding cultivar adaptations to ensure precise deficit irrigation [11]. Similarly, the ratio of irrigation water need to groundwater recharge (IGR ratio) was assessed based on the distributed water balance model mGROWA, a deterministic distributed water balance model developed at the Forschungszentrum Jülich on behalf of the Ministry for the Environment, Energy and Climate Protection of Lower Saxony, German, in cooperation with the State Agency for Mining, Energy and Geology, it has been developed to determine water balance variables, including groundwater recharge in large areas under present and possible future climate conditions, which showed that the delineated vulnerable areas coincide with the field regions for which high irrigation quantities from groundwater resources had been previously documented [12].

Regarding the performance of effective water allocation in surface irrigation, there is an investigation on the soil texture, plot size, and farmers' practices significantly affect water allocation efficiency and surface irrigation performance [13]. Reference [14] indicated that variable alternate furrow irrigation (VAFI) reduces the winter wheat grain yield, dry matter, and grain number per spike. Fu et al. used chaos theory to analyze the water resource allocation mechanism behind the response of irrigation water use efficiency (IWUE) to precipitation in specific agricultural irrigation districts [15]. By analyzing the factors influencing water allocation mechanism, Liang et al. studied the concentration prediction of irrigation effectiveness and the four-dimensional fuzzy correlation in water allocation [16,17]. Table 1 lists several key factors influencing irrigation water allocation and summarizes the latest investigations on this subject, including the following:

(1) More precise allocation method of irrigation water resource allocation under different precipitation conditions and uncertain water supply;

(2) providing sufficient and efficient compensation for the losses due to moisture evaporation, and developing water-saving irrigation technologies during the process of precision irrigation;

(3) installing moisture-monitoring probes in soil fields and enhancing the supervision system of water allocation for better adapting to the actual irrigation environment; and

(4) studying the consumptive elements of irrigation water and investigating the transfer of non-consumptive water allocation factors. 
Table 1. Key influential factors for water allocation mechanism in precision irrigation.

\begin{tabular}{|c|c|c|c|c|c|c|c|}
\hline $\begin{array}{l}\text { Approaches } \\
\text { and Methods }\end{array}$ & 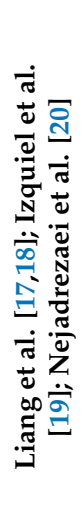 & 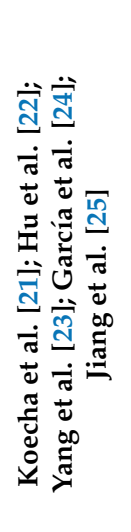 & 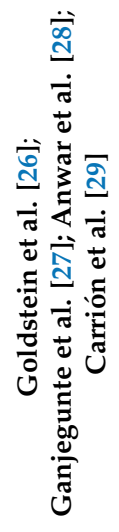 & 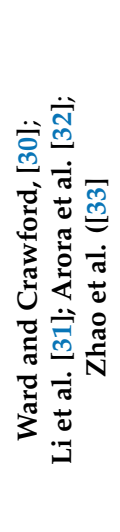 & 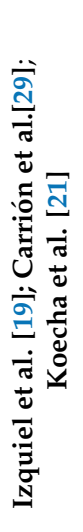 & 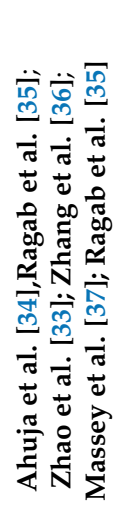 & $\begin{array}{l}\text { Application Methods and } \\
\text { Experimental Conditions }\end{array}$ \\
\hline $\begin{array}{l}\text { Prediction and } \\
\text { monitoring }\end{array}$ & * & $*$ & & $*$ & & * & $\begin{array}{l}\text { Adaptive Network-based Fuzzy } \\
\text { Inference System (ANFIS); Design } \\
\text { of Reservoirs of regulation in } \\
\text { On-Demand Irrigation } \\
\text { Networks (DRODIN) }\end{array}$ \\
\hline $\begin{array}{l}\text { Irrigation } \\
\text { scheduling } \\
\text { and planning }\end{array}$ & * & & * & * & $*$ & * & $\begin{array}{c}\text { Flexible Irrigation Scheduling } \\
\text { Decision Support System (FIS-DSS) }\end{array}$ \\
\hline $\begin{array}{c}\text { Irrigation } \\
\text { management }\end{array}$ & * & & & * & & * & $\begin{array}{l}\text { Pressurized irrigation system; } \\
\text { minimum total annual cost; } \\
\text { irrigation decision- making; } \\
\text { structural equation model }\end{array}$ \\
\hline $\begin{array}{l}\text { Stability of soil } \\
\text { water content }\end{array}$ & * & * & & * & $*$ & & $\begin{array}{l}\text { Variable Rate Irrigation (VRI); } \\
\text { t-copula function; power } \\
\text { conversion coefficient }\end{array}$ \\
\hline Field layout & & * & & & * & & $\begin{array}{l}\text { Improve water allocation } \\
\text { mechanism performance }\end{array}$ \\
\hline
\end{tabular}

Since irrigated agriculture requires high-performance reliability from water delivery networks and high flows to satisfy various technological demands at seasonal peak times, the use of satellite imagery to aid with precise water allocation has become a hot topic [38]. The monitoring of crop water consumption, also known as actual evapotranspiration (ETa), through the use of satellite imagery and remote-sensing-based monitoring algorithms is crucial for constructing prudent allocation strategies using limited freshwater resources [39]. Inspired by this situation, Trezza et al. completed a crop estimation of evapotranspiration (ETc) using satellite images to obtain the normalized difference vegetation index (NDVI) for precise water allocation [40]. Since the dynamics of maize, alfalfa, fruit trees, and poplars can be analyzed using greenness and wetness extracted from satellite remote sensing data [41], Zhang et al. proposed an intelligent water allocation method for farmland irrigation and drainage system based on domestic high-resolution satellite images, which considered both spectral features and geometry features of farmland irrigation and drainage system [42,43]. Their experimental analysis demonstrated that the accuracy of satellite imagery satisfies the water allocation need for large-scale and rapid extraction for precise irrigation and drainage systems [44]. Similarly, Araya et al. successfully mapped the seasonal cultivated area based on satellite images, and combined water allocation information from multiple bands to characterize the land surface in terms of spectral indices, such as NDVI and surface temperature (Ts) [45]. The capability of crop water stress index (CWSI), based on satellite thermal infrared data for estimating water stress and irrigation scheduling, was evaluated [46]. They found that water allocation schedules can be monitored using satellite imagery without any need for ground ancillary data. In the past several years, relevant water allocation tests were undertaken for crop cultivation by applying the Penman-Monteith method [47], e.g., the disaggregation based on physical and theoretical scale change (DISPATCH) algorithm was 
proposed to downscale soil moisture satellite data by combining the low-resolution Soil Moisture Ocean Salinity (SMOS) satellite soil moisture data with the high-resolution NDVI and land surface temperature (LST) datasets [48]. Satellite imagery could also be used to determine and compare the water allocation variations; some investigations assessed the risk of land degradation and water allocation changes using Landsat Thematic Mapper (TM) and Spectral Mixture Analysis (SMA) [49,50]. Others confirmed that the efficacy of high-resolution remote sensing images and the maximum likelihood method in estimating water allocation [51]. Inspired by this method, Laura et al., presented HidroMap as a geographic water allocation information system (GIS) organized in two different modules, desktop-GIS and web-GIS, with complementary functions based on the PostgreSQL/ PostGIS database [52]. Saraiva et al. detected the center pivot irrigation systems to a constellation of planet scope images, which provides an important support tool for water/soil management and water allocation decision making [53]. Corbari et al. and Ali et al. found that satellite-driven image models and meteorological forecasts could provide support for smart water allocation systems [54,55]. Correspondingly, Knipper et al. investigated the utility of satellite-derived maps of evapotranspiration (ET) and the ratio of actual-to-reference ET (fRET) based on the remotely sensed land surface temperature (LST) imagery [56]. Tan et al. also reported the potential of the ET strategy using satellite-based imagery monitoring of water consumption dynamics [3]. All these investigations confirmed the potential of using satellite imagery to aid in precise water allocation.

These theoretical and technical investigations formed a consistent vision of the water allocation mechanism for precision irrigation system, providing a solid basis for analysis in this systematic review.

\section{Integrative Management Effectiveness of Precision Irrigation}

The integrative management effectiveness of precision irrigation can be regarded as the operational effect or maintenance influence when all the components of the irrigation system are used together to achieve the objective of optimal agricultural irrigation. The implementation of integrative irrigation management requires a harmonized application of management tools, including the schedule models, on-site monitoring systems, remote sensing, etc., ultimately leading to the collaborative development of crop cultivation based on practical meteorological conditions and current soil/plant water need.

To guarantee the optimal performance of a precision irrigation system, three major steps are required:

(1) Generic model definition for integrative management effectiveness. The existing irrigation methods based upon specific flow models are poorly coupled with generic management approaches. Therefore, it is necessary to define the generic management effectiveness of both the working principle and the collaborative behavior of irrigation system to enable accurate verification for system collaboration;

(2) model-driven integrative management effectiveness. This task is dedicated to proving the validity of integrative management effectiveness by generating a fully-functional irrigation schedule conforming to previous management models. This task should be supported by irrigation expertise in the field of resource distribution model transformations;

(3) formal verification of integrative management effectiveness. This task is meant to evaluate the feasibility of applying formal verification to integrative management effectiveness to prove the unique properties of an irrigation system that are valuable for agricultural productivity control. Given the expected management results, information feedback from the water/soil resource management might be required to refine the proposed control methods to achieve irrigation management objectives.

From the above-mentioned analysis, based on the generic model definition step for integrative management effectiveness, a novel model of Linked Simulation Optimization (LSO) matched to the Clonal Selection Algorithm (CSA) was formulated for conjunctive irrigation management [57]. Ghumman et al. investigated the operations of an upstream control irrigation system with respect 
to management effectiveness [58]; the results indicated that excess supply of water to the irrigation system could be saved. From their demonstrations, the management effectiveness would help improve irrigation operations where satisfactory irrigation conditions are available.

Based on the investigation step of model-driven integrative management effectiveness, the current on-farm irrigation management methods for maize, water equity, and crop productivity can be enhanced using genetic algorithms in the Doroodzan network of agricultural irrigation [59]. Similarly, there are some researches suggested that integrative irrigation treatments, namely full drip (DT), full border (BT), deficit drip (DDT), and deficit border (DBT) irrigation treatments, tended to increase WUE and field yield, which confirmed their satisfactory effects on crop returns [60-62].

To assess the integrative management effectiveness of irrigation density, Mangalassery et al. indicated that in areas with limited facilities for field irrigation, appropriate management of water resources can considerably increase the fruit yield and net income [63]. Goldhamer et al. provided a set of management information that could be used in irrigation decision-making conditions, including how to evaluate the risks and rewards of seeking/acquiring additional water supplies in an unsatisfactory environment [64]. Zema et al. strategically analyzed irrigation water delivery to determine whether the optimal integrative management effectiveness of precision irrigation is possible by implementing measurement at a lower cost compared to structural irrigation works [65]. An effectiveness simulation compares traditional irrigation with the integrative managed water supply, and illustrated the notion of integrated resource management effectiveness for complex irrigation communities [66].

Soil salinization is a key issue in irrigated areas as it substantially impacts crop productivity. It is a widespread problem and a major abiotic constraint affecting global food production and threatening food security. Morshed et al. attempted to detect soil salinity using remote sensing and geographic information system [67]. Current investigations have focused on effective methods to prevent soil salinization through effective management of irrigation applications. For instance, Li et al. evaluated the utility of field-derived spectra of saline soils and related vegetation for characterizing and mapping the spatial distribution of irrigation-induced soil salinization [68]. Navarro et al. focused on the mutual relationship between saline water evaporation from soil surfaces and water table depths [69,70]. Macroscopic numerical simulations demonstrated that higher soil concentrations of salinity in deeper water tables are attributed to less evaporation [23]. Groundwater level is the main factor affecting the distribution of soil salinity, but the response relationship between the spatial distribution of soil salt and the groundwater level remains unclear [71]. To clarify the patterns of soil salinization responding to precision irrigation, Liang et al. [16,17] and Singh et al. [72] contributed excellent achievements in the domain of quantitative calibration domain of irrigation effect.

Since partial root drying irrigation (PRD) is a representative water-saving technique and is performed as a control measure of groundwater nitrogen contamination, Barzegari et al. evaluated the interaction effect of ordinary furrow irrigation (OFI), PRD irrigation as the variable alternate furrow irrigation (VAFI), and fixed alternate furrow irrigation (FAFI), with different nitrogen application rates on yield quality, drainage water, nitrogen leaching, nitrogen uptake, and nitrogen efficiency indices through the application of integrative management of precise root drying irrigation [73]. The amount of $\mathrm{N}$ fertilizer should be reduced in proportion to the amount of water available under VAFI. In support of this conclusion, probability distribution functions (PDF) were used to control the applied water depth by high-efficiency management of irrigation equipment [74]. The management analysis provided an important effectiveness reference for water resource distribution under irrigation conditions.

As decision making is one fundamental intelligent property for integrative irrigation management, it can be derived as choice and ranking composed of irrigation conditional preparation, soil parametric monitoring, irrigation logic triggering, design of operational decisions, irrigation effectiveness evaluation, and application of irrigation decisions, which are recursive and can be implemented in different layers of management architectures. Since an eco-hydrological model, called the soil and water assessment tool (SWAT), is used worldwide for simulating hydrology and water quality of agricultural catchments, Maier et al. experimented with the application of SWAT for constructing 
appropriate irrigation management strategies [75]. Their integrative managed results showed that by using deficit control strategies and intelligent decision-making, the water consumption could be remarkably reduced with only a moderate decrease in crop yield, verifying the promising and positive influence of integrative irrigation management on crop water use.

As integrative irrigation management is generally based on the coordinated measurement and instantaneous control of soil water content or meteorological parameters for modeling evapotranspiration, Alghory and Yazar evaluated the crop water stress index (CWSI) according to the conventional irrigation management strategies [76]. The obtained relationships could be employed for predicting the yield response to water stress. The efficient use of irrigation water remains a major concern because of increasing competition for water resources and the pressing need to enhance crop productivity worldwide. A decision-making tool for irrigation management was therefore developed to enhance water use with reference to the proposed soil water balance and crop water satisfaction models [77]. However, subjectively establishing irrigation management schemes often result in excessive water use and significant fertilizer leaching [78]. Using stem psychrometers to directly measure plant water status (PWS), the relationship between water stress, prevailing environmental conditions, and species-specific stress-tolerance thresholds can be characterized to enable high-efficiency integrative management effectiveness. Table 2 describes the key influential factors for integrative irrigation management. More innovative achievements in effectiveness verification and performance assessment can be referenced from the literature [79-82].

(1) The basic goal of precision irrigation to increase agricultural yield with minimum water input and reduced environmental pollution. This is required in developing countries and small-scale farms. However, the high-tech nature of the precision irrigation developed in advanced countries poses challenges for small-scale farmers, ordinary agricultural enterprises, and technical engineers when finding suitable irrigation technologies in developing countries such as China, Brazil, and India. The challenges include the technology level, the real-time data processing capability, and the cost of implementing and maintaining irrigation applications [41]. As small-scale farms are responsible for about $80 \%$ of irrigated agriculture in developing countries and their importance in contributing to the global agricultural production chain is expected to increase in the future $[3,39]$, it is necessary to design simple, low-cost, and data-effective measures for water allocation and their integrative management to assist socio-economic development. Precision irrigation embraces the concept of sustainable intensification of agricultural production by reducing water inputs by achieving a precise soil/moisture equilibrium. An irrigation application mechanism is required that allows visualization and compilation of the data measured by moisture and $\mathrm{pH}$ sensors used in a smart agriculture system. This application minimizes the users' direct interaction with the irrigation control system while improving convenience and the control of the irrigation process when required. Using this irrigation application mechanism, the farmer can monitor, collect, and process soil and irrigation information at a low cost.

(2) The application of balanced precision irrigation technologies is expected based on the specific socio-economic conditions in developing countries and small-scale farms. Here, precision irrigation mainly depends on the parametric calibration of crop cultivation and soil management based on fuzzy decision-making rather than on empirical and visual analyses. Motivated by this tendency, construction and maintenance technology for precision irrigation and drainage works should be appropriate for developing countries.

(3) Encourage small-scale farmers/users in developing countries to use the Internet to obtain free information on the soil and water properties of agricultural farms using irrigation. Geographic information system (GIS) has been used to support agricultural irrigation. In the interest of farmers and agricultural enterprises, internet control and related intelligent techniques have been incorporated into the irrigation apparatus; thus, the costs of systems managers could be markedly reduced, so high-speed data/information connectivity systems (computers/Internet) need to be 
developed in rural areas. This system could be used to automatically identify which areas are suitable for arable land and to determine the best crop for a particular region.

(4) Appropriate irrigation solutions enable small-scale farmers to become agricultural experts by using modern farming concepts and advanced irrigation equipment, or service provider entrepreneurs selling irrigation technologies in the rural areas in developing countries. A planned number of irrigation tests and data analyses are required after the application of precision irrigation. Future strategies for the adoption of precision irrigation should consider the problems of land fragmentation, the lack of highly sophisticated technical centers, specific software for precision irrigation, and the poor economic condition, in general, of farmers in the developing world.

(5) Though integrating all these newly-proposed techniques into precision irrigation applications, more benefits than costs are generated for practical agricultural production conditions. The precision irrigation practices currently being implemented provide opportunities for alternative practices to increase agricultural irrigation effectiveness in those developing countries while minimizing the negative impacts on the working environment. To realize this, close collaborative efforts are needed among farmers, agricultural enterprises, farm associations, community groups, machinery manufacturers, research and extension agencies, and other public and private agencies, to effectively reduce the agricultural production costs and make the improved precision irrigation technique more suitable for the practical requirements of farmers and users in the developing world.

Table 2. Key influential factors in integrative management effectiveness in precision irrigation.

\begin{tabular}{|c|c|c|c|c|c|c|c|}
\hline Objectives & 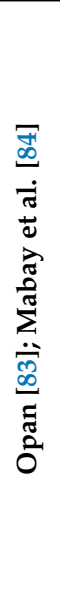 & 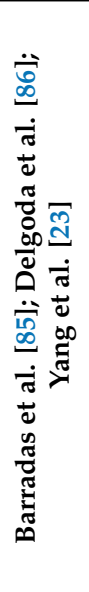 & 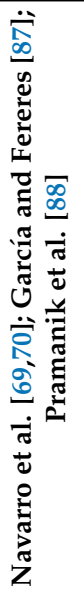 & 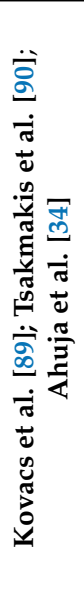 & 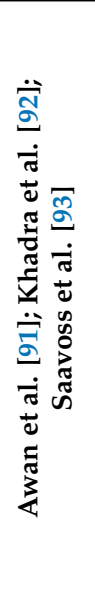 & 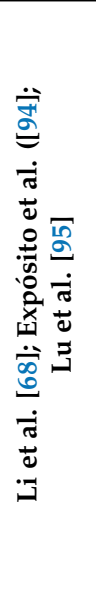 & $\begin{array}{l}\text { Investigation Results and Technical } \\
\text { Improvements }\end{array}$ \\
\hline Sustainability & & * & * & & & * & $\begin{array}{l}\text { Data processing suppliers } \\
\text { association (DPSA) }\end{array}$ \\
\hline Predictive control & * & & & & * & * & Markov decision process (MDP) \\
\hline Adaptivity & & * & & * & * & & R-model predictive control (RMPC) \\
\hline $\begin{array}{l}\text { Cultivation } \\
\text { productivity }\end{array}$ & * & & * & * & * & & Large-scale withdrawals of groundwater \\
\hline $\begin{array}{l}\text { Trade-off between } \\
\text { water and energy }\end{array}$ & * & & & * & * & * & Interoperable model coupling system \\
\hline
\end{tabular}

To determine unique irrigation properties and verify the effectiveness and reliability of integrative management, Saini et al., carried out a field experiment using different planting methods and irrigation schemes [96]. The best applicable irrigation parameters that lead to significant reductions in total water use and characterize soil moisture spread along furrow were determined [72]. The rate of water discharge and the cut-off length of furrow should be considered to increase IWUE for improving management effectiveness. The impacts of irrigation management strategies on soil and plant water status and fluxes in photosynthesis and chamber transpiration were studied [97]. Their effectiveness verification results showed that, with the exception of the regulated deficit irrigation (RDI) treatment, 
water stress increase reduces the physiological parameters of an irrigation system due to stomatal and non-stomatal limiting factors. Motivated by this finding, Laurenson et al. monitored the soil-water dynamics with a center-pivot irrigation system on rolling lands [98]; they found the irrigator should check excess water consumption and reduce the infiltration rate and wetting soil depth of precision irrigation to increase water productivity. Similarly, Wu et al. proposed a risk management analysis model for quantifying the risk of crop production due to the variation in moisture infiltration and cultivation area or uncertainty of agro-climate factors, such as the total precipitation, average emperature, total sunshine, and average solar radiation, which reflect climate change, irrigation water quality, surface water, and groundwater level, respectively [71]. Some other existing problems could be addressed, such as management effectiveness comparisons and dynamic integrative coordination between irrigation components, subject to various agricultural production conditions.

Based on the objectives and the implementation framework of modern integrated water resources management (IWRM), Pan et al. estimated the effect of the human organization on the management performance of water resources [99]. To increase irrigation production, they found that public participation must be developed, administration ability must be improved, and sufficient financial support must be provided for irrigation management organization. Rouge et al. identified key water resource vulnerabilities by considering the stability of human organization [100]. Based on this idea, agricultural management organizations should propose effective measures for irrigation promotion according to the actual irrigation situation $[33,101]$. Shindo et al. tried to increase the working efficiency of management organizations, by eliminating excess water intake and reducing the number of water conflicts [102].

Considerable evidence show that irrigation infrastructure is playing an increasingly important role in promoting the technical developments of precision irrigation, while irrigation infrastructure is improving the measurement accuracy of water allocation, robustly maintaining the equilibrium of agricultural water provision [103]. Wang et al. investigated the role of local irrigation infrastructure in improving farmers' ability to respond to drought [104]. Together with its infiltration effectiveness in mitigating the drought risk during agricultural crop production, they found that irrigation infrastructure contributes to enhancing farm production capacity in adapting to drought, simultaneously increasing mean yield and reducing risk exposure in crop cultivation. Watts et al. demonstrated that the adaptive management of irrigation infrastructure helps to improve infiltration effectiveness through effective organization collaboration and the timely provision of irrigation monitoring results [105]. Suhardiman and Diana urged the development of several effective water management organizations for farmers, and regarded infrastructure-oriented development as the basic foundation for effectiveness promotion [106]. Paranage et al. also concluded that the construction of water infrastructure influences the degree of irrigation users' dependence on each other [107]. So, based on these descriptions, the constructive effects of real-time irrigation water resources, irrigation infrastructure, and management organizations on the water allocation mechanism and integrative management of precision irrigation, could be clearly determined.

As a brief summary, Figure 2 explains the aspects concerning the integrative management effectiveness of precision irrigation, which cover the majority of agricultural irrigation applications, including its importance and necessity, application characteristics, optimization design, allocation mechanism, intelligent controlling, and allocation influence. All these aspects contribute to the systematic investigation of integrative management effectiveness of precision irrigation from unique perspectives. 


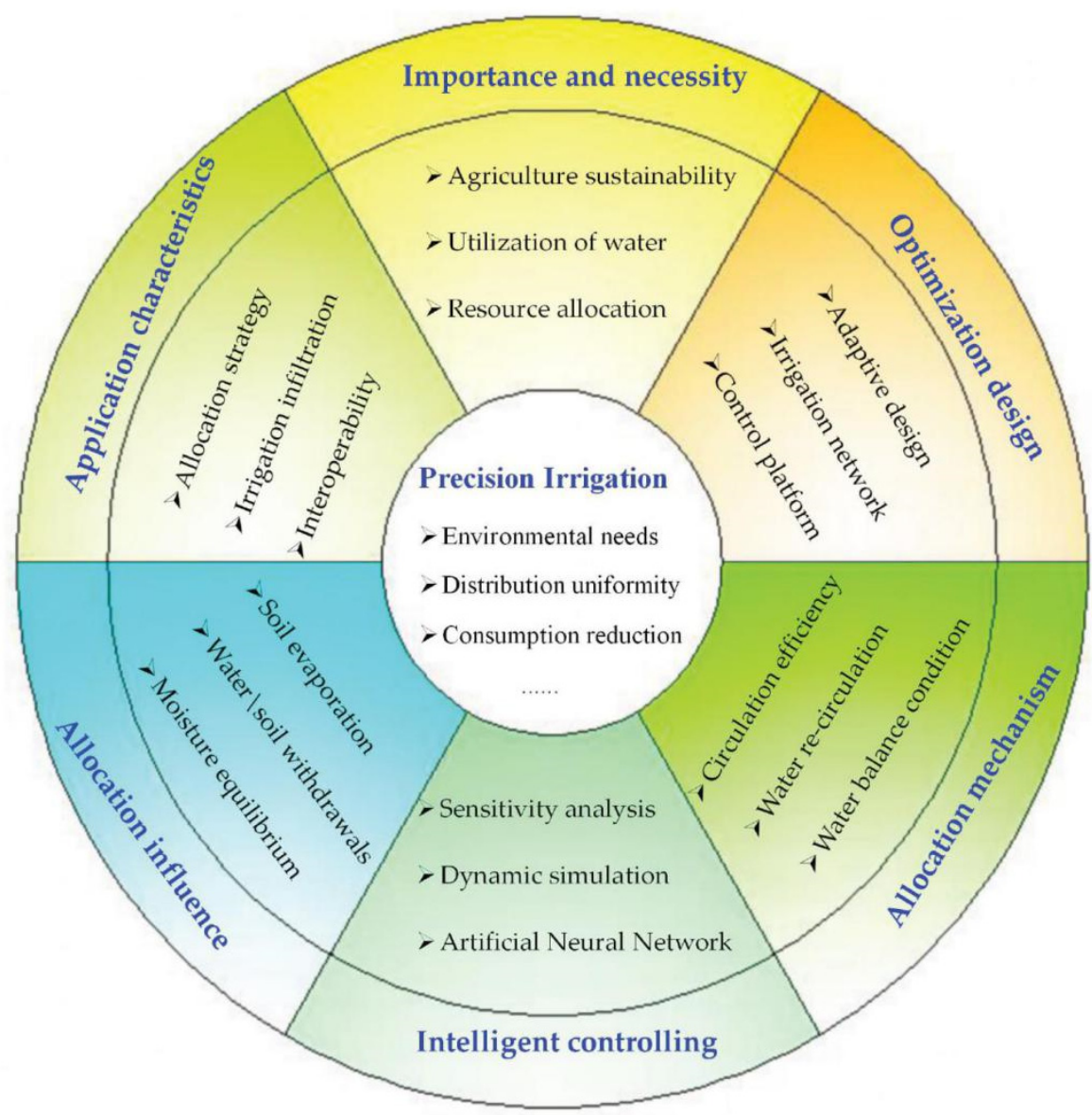

Figure 2. The inclusive subjects discussed in integrative management effectiveness of precision irrigation.

\section{Future Development Prospects}

The rapid development of precision irrigation techniques, together with their constructive applications and comprehensive influences, already covers most of the agricultural and horticultural domains. They presented systematic irrigation investigations into new areas of environment correlation and cultivation effectiveness. In this review, we use literature bibliometrics diagrams to describe the research advances in precision irrigation in water allocation and integrative management. These diagrams use hierarchical data to display the influence of key research subjects and logical correlations within the irrigation domain, demonstrating the influence structure and citation relationships. Within literature bibliometrics, the fundamental assumption is that the frequency with which a set of research papers being referenced is a measure of the impact or influence of research subjects, by counting the real-time publications and citations within influential irrigation journals. Using this method, scientific precision irrigation results can be communicated visually through diagrams, visualizations, and photographs. The combination of an investigation subject, development level, and constructive influence provide a unified framework for research analysis.

Using the newly-developed bibliographic citation analysis data ranging from soil quality to moisture infiltration rates, we classified more than 700 published irrigation papers into approximately 30 separate fields and several research levels. Literature bibliometrics searches for a large number of documents to classify the figures, organize the results and conclusions into a cloud-hosted database, and finally drive distinct applications to support bibliometric analysis and information retrieval. Herein, the fields of water supply and soil moisture equilibrium were found to have the highest citation influence in the past several years. A figure processing mechanism was used to classify different investigation topics and to study the resulting patterns of data information in relation to technological impact. A significant correlation between scientific impact and data information was 
identified. Therefore, we used these bibliometric results to articulate the organization and presentation of irrigation investigation.

Figure 3 depicts a literature bibliometrics diagram drafted by VOSviewer (Developed by the Research Centre for Science and Technology Studies, Leiden University, PO Box 9500, 2300 RA Leiden, The Netherlands), which is a software useful tool for constructing and visualizing bibliometric radial networks that were used for precision irrigation investigation in this review. These informative networks extract data from journals, researchers, or individual publications, and they can be constructed based on co-citation, bibliographic coupling, or co-authorship relationships. VOSviewer also offers a text-mining functionality that can be employed to construct and illustrate co-occurrence networks of important terms searched from the scientific literature. From the text mining, in the label view of VOSviewer, different research items are highlighted by colored circles. Its font and circle sizes depend on the weight of the subject item and hierarchical data structure. VOSviewer shows that in the water allocation mechanism of precision irrigation, the subjects of recent focus can be roughly categorized into the following four groups:

(1) Water allocation schedule and resource arrangement mechanism, demonstrating that some important subjects, especially water allocation procedure, water quality, infiltration rate, irrigation interval, arrangement complication, and water saline, have strong connections with actual applications of water allocation schedules or are considerably influenced by the resource arrangement mechanism;

(2) water allocation performance index, demonstrating that some important subjects, especially moisture concentration, water quality, infiltration uniformity, the water use coefficient, crop species, and water resource filter, have contributed to the optimization of water allocation performance;

(3) resource allocation policy and adaptive water supply mechanism, demonstrating that some important aspects, especially agricultural production policy, dynamic irrigation simulation, environmental water supply, irrigation net-benefit, mechanism optimization, adaptive water supply calibration, and actual irrigation climate, have strong connections with the actual application of agricultural resource allocation policy or are strongly influenced by adaptive water supply mechanism;

(4) field productivity and yield statistics, demonstrating that some important factors, especially tillage science, fertilizer distribution, soil condition, crop yield, field big-data, water drainage, annual harvest emission, actual farm income, and water use efficiency, showed a close relationship with field productivity or could be accurately analyzed using yield statistics.

Correspondingly, Figure 4 is a literature bibliometrics diagram drafted by VOSviewer. In the domain of integrative management effectiveness of precision irrigation, its recently-focused subjects can be roughly categorized into the following five groups:

(1) Management strategy and effectiveness assessment, demonstrating that some important areas, especially irrigation quality, water-use protocol, field moisture evaporation, water-saving strategies, soil surface characteristics, and the threshold value of irrigation decision-making, have strong connections with actual irrigation management or are clearly affected by irrigation effectiveness assessment;

(2) resource management effect and field productivity, demonstrating that some important aspects, especially water resource balance, water distribution competition, crop productivity, agriculture growth stage, air humidity, and management limitation, have contributed to the integrative investigation of resource management effect and field productivity;

(3) management network and promotion capability, demonstrating that some aspects, especially irrigation control, moisture infiltration volume, irrigation sensor network, irrigation control capability, productivity prediction reliability, environmental moisture, irrigation monitoring operation, and simulation software for precision irrigation, connect with the management network and facilitate promotion capability during precision irrigation processes; 
(4) irrigation parametric coefficient and management limitation, demonstrating that some important areas, especially remote sensing of irrigation parameters, actual water demand, irrigation field mapping, moisture infiltration coefficient, and greenhouse productivity, showed a close relationship with irrigation parametric coefficient, or limit irrigation management; and

(5) resource supply and management scenarios, demonstrating that some important subjects, especially data calculation for resource management, environmental water status, crop canopy, water potential capability, air temperature, supply indicator for water resource, soil moisture ratio, and soil source management, have strong connections with the actual applications of agricultural resource supply or are demonstrated in management scenarios.

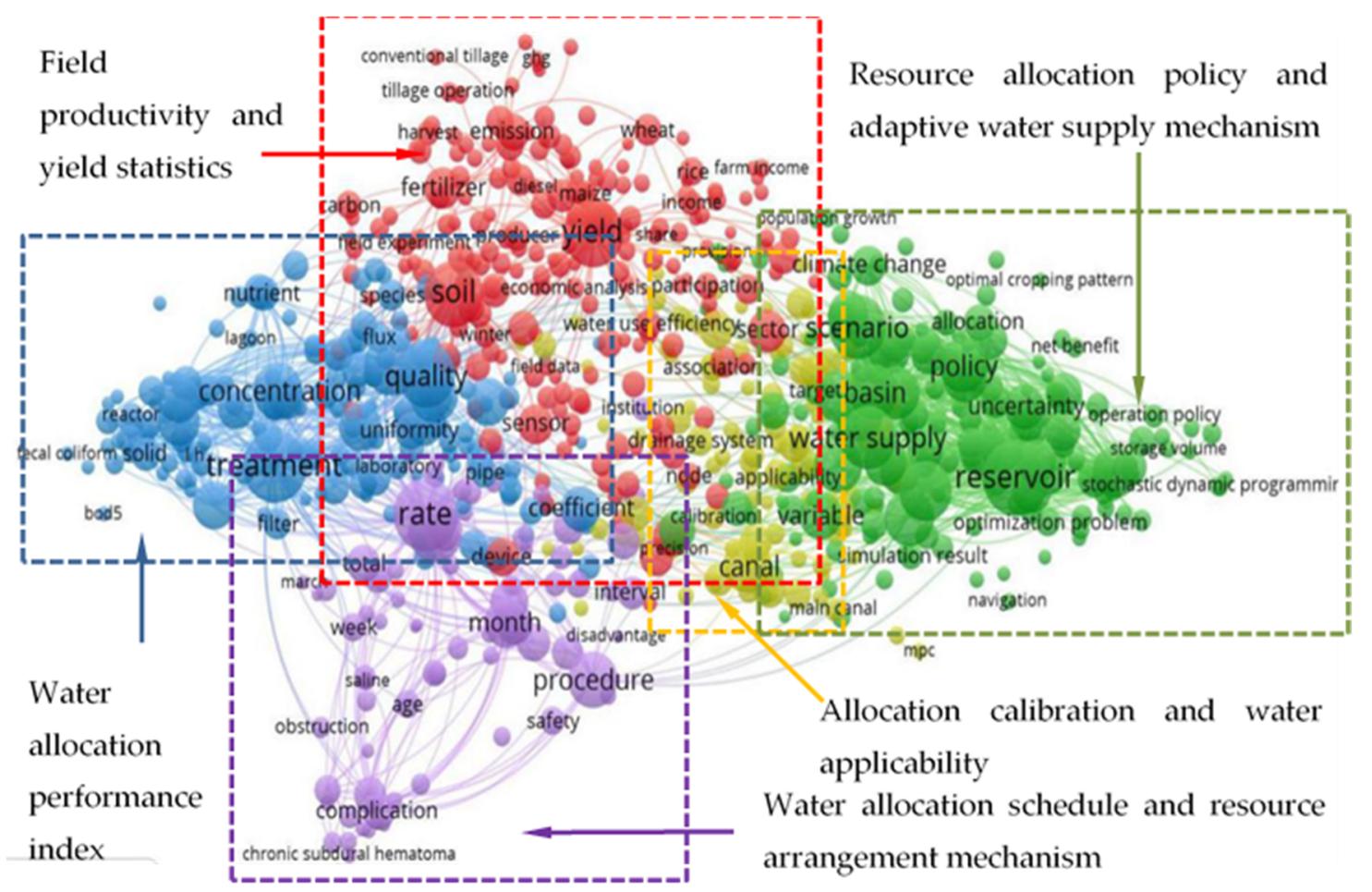

Figure 3. Bibliometrics diagram concerning the most-relevant keywords in the water allocation mechanism of precision irrigation, the focused topics and their mutual correlations investigated from 1999-2019 can be described and highlighted.

From the aforementioned analysis, the contributions of water allocation mechanism and appropriate integrative management effectiveness to precision irrigation can be summarized as follows:

(1) Optimal water resource allocation toward connected, autonomous and, decentralized decision support for precision irrigation systems,

(2) dynamic water resource allocation coordination toward adaptability and improved real-time control capabilities in complex irrigation processes,

(3) data-oriented irrigation monitoring architecture toward big data analysis and distributed intelligence networks throughout the whole irrigation operation,

(4) product-centric control approach for precision irrigation process toward integrative management effectiveness and irrigation data adaptivity,

(5) web-oriented irrigation management principles toward service orientation and secure communication between different components of an intelligent irrigation system, and ensure their optimal coordination, 
(6) synthesis of integrative management effectiveness to meet precision irrigation requirements in actual agricultural production conditions.

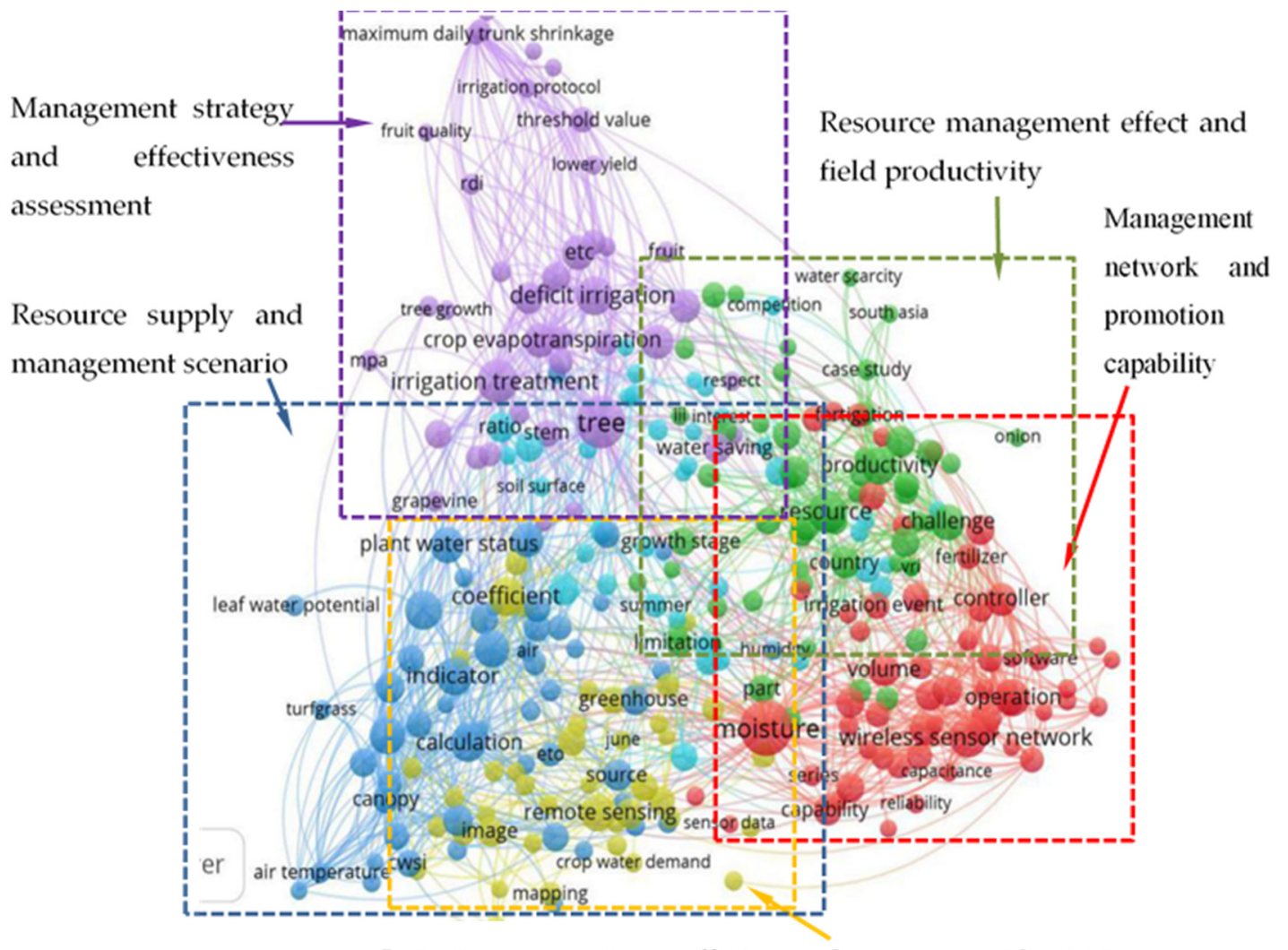

Irrigation parametric coefficient and management limitation

Figure 4. Bibliometrics diagram concerning integrative management effectiveness of precision irrigation.

As studies on these topics have rapidly increased, several major theoretical and technical subjects should be investigated.

(1) Water allocation improvement. The currently-used irrigation methods are mainly based on inappropriate water allocation. Specific water concentration is rarely the focus, and generic moisture infiltration has been poorly analyzed. It is, therefore, necessary to design and use accurate models of water allocation to enable the accurate prediction of water infiltration to improve irrigation effectiveness. This task is dedicated to validating the water allocation mechanism by generating a fully functioned irrigation scheme that conforms to previous water resource allocation models.

(2) Formal verification of moisture infiltration and water resource allocation efficiency to evaluate the feasibility of applying operational verification to the irrigation scheduling models defined previously to verify the environmental adaptivity of irrigation approaches that are valuable for the temporal monitoring of crop cultivation. Considering agricultural productivity, feedback loops in water allocation models might be necessary to refine irrigation efficiency and schedule reliability to reach the predetermined target of field productivity.

(3) Environment-oriented decision making. The increase in monitoring information connectivity between irrigation systems and environmental conditions, enabling highly-efficient crop cultivation through the integrative irrigation management network. Integrative irrigation management synchronizes the sprinkling precipitation of representative crop cultivation sites. This objective poses a challenge as the adaptive response time of irrigation decision-making 
networks is incompatible with those needed for agricultural production control. An innovative water irrigation monitoring approach integrating multi-level schedule applications and implementing novel irrigation services for multi-objective irrigation optimization would help realize intelligent irrigation.

(4) Irrigation process virtualization-promoting integrative management effectiveness. The management features of aggregation and autonomy inherent to precision irrigation systems are of concern for the novel design and effective operation of adaptive management strategies. The virtualization of integrative management effectiveness should be defined and the collaborative irrigation process between the decision-making stage and the irrigation implementation stage should be studied to demonstrate the effectiveness of integrative management and make it available for other process virtualizations of precision irrigation.

(5) Sustainability-resource efficiency. Resource management through the notion of intelligent irrigation requires massively distributed, scalable, and coordinated control, for which a comprehensive perspective will be relevant. Control of precision irrigation activity for crop cultivation or agricultural production will also be affected by the availability of resource consumption from the soil, field, or irrigation water. This final direction is largely based on the connectivity of irrigation resources using efficiency, which provides accurate access to the instant and planned resource consumption needed for irrigation scheduling, intelligent decision-making, and high-efficiency precision irrigation implementation afterward.

The most-cited development tendencies and expanding application areas of irrigation models, together with their influential factor contributions, are illustrated in Table 3. Based on this description, it analyzes the technique advantages, development prospects, and representative application cases, of irrigation models in actual agricultural production. Table 3 indicates that such typical models and irrigation techniques as DSSAT, ACO/LIDM, AquaGIS, SWAP, AquaCrop, etc., were employed in deficit irrigation, pressurized irrigation, and dynamic water allocation, for small farmers in developing countries, including India, Turkey, Brazil, and China. With the help of these models and techniques, the focused irrigation topics could be determined conveniently.

Table 3. The advantages and development prospects of representative irrigation models.

\begin{tabular}{|c|c|c|c|c|c|}
\hline No. & Models & Advantages & $\begin{array}{l}\text { Development } \\
\text { Prospects }\end{array}$ & $\begin{array}{c}\text { Representative Cases of } \\
\text { Actual Application and } \\
\text { Systems }\end{array}$ & References \\
\hline 1 & DSSAT & $\begin{array}{l}\text { Optimum } \\
\text { collaboration of } \\
\text { irrigation factors }\end{array}$ & $\begin{array}{l}\text { Irrigation water } \\
\text { effectiveness } \\
\text { measurement }\end{array}$ & $\begin{array}{l}\text { Irrigation performance } \\
\text { assessment for crop deficit } \\
\text { irrigation at the tertiary canal } \\
\text { level in the Nile Delta of Egypt }\end{array}$ & {$[5,35]$} \\
\hline 2 & ACO/LIDM & $\begin{array}{l}\text { Optimize the irrigation } \\
\text { characteristics from } \\
\text { chaotic data }\end{array}$ & $\begin{array}{l}\text { Data-oriented } \\
\text { artificial } \\
\text { intelligence } \\
\text { irrigation }\end{array}$ & $\begin{array}{l}\text { Optimal network construction } \\
\text { for sprinkler and drip } \\
\text { irrigation in Cuenca, Spain }\end{array}$ & {$[2,22]$} \\
\hline 3 & AquaGIS & $\begin{array}{l}\text { Real-time feedback } \\
\text { integrating } \\
\text { environmental } \\
\text { information }\end{array}$ & $\begin{array}{l}\text { Improvement } \\
\text { of soil moisture } \\
\text { uniformity }\end{array}$ & $\begin{array}{l}\text { Increasing water productivity } \\
\text { in an irrigation district in the } \\
\text { Hei River Basin, China }\end{array}$ & {$[18,71]$} \\
\hline 4 & SWAP & $\begin{array}{c}\text { Corroborative } \\
\text { schedule of irrigation } \\
\text { efficiency }\end{array}$ & $\begin{array}{l}\text { Regulation of } \\
\text { irrigation } \\
\text { information } \\
\text { collection }\end{array}$ & $\begin{array}{l}\text { Pressurized irrigation } \\
\text { effectiveness evaluation } \\
\text { among olive farmers in } \\
\text { northern Iran }\end{array}$ & {$[32,72]$} \\
\hline
\end{tabular}


Table 3. Cont.

\begin{tabular}{|c|c|c|c|c|c|}
\hline No. & Models & Advantages & $\begin{array}{l}\text { Development } \\
\text { Prospects }\end{array}$ & $\begin{array}{c}\text { Representative Cases of } \\
\text { Actual Application and } \\
\text { Systems }\end{array}$ & References \\
\hline 5 & AquaCrop & $\begin{array}{l}\text { Accurate and efficient } \\
\text { distribution planning } \\
\text { of water resource }\end{array}$ & $\begin{array}{l}\text { Impact } \\
\text { assessment of } \\
\text { adaptively } \\
\text { alternate } \\
\text { irrigation }\end{array}$ & $\begin{array}{l}\text { Dynamic water allocation for } \\
\text { converted paddy fields of } \\
\text { Huai River in Anhui, China }\end{array}$ & {$[27,92]$} \\
\hline 6 & SEBAL & $\begin{array}{l}\text { Exploiting the } \\
\text { self-learning ability for } \\
\text { water distribution }\end{array}$ & $\begin{array}{l}\text { Surface runoff } \\
\text { and drainage } \\
\text { control }\end{array}$ & $\begin{array}{c}\text { Performance monitoring of } \\
\text { water-saving irrigation and } \\
\text { water conservancy project in } \\
\text { Telangana, Indian }\end{array}$ & {$[8,54]$} \\
\hline 7 & FAO-AZM & $\begin{array}{l}\text { Adaptability in } \\
\text { precision irrigation } \\
\text { system }\end{array}$ & $\begin{array}{l}\text { Water balance } \\
\text { of } \\
\text { agro-ecosystems }\end{array}$ & $\begin{array}{l}\text { Irrigation distribution } \\
\text { uniformity analysis on a } \\
\text { lateral-move crop irrigation } \\
\text { system in Mato Grosso, Brazil }\end{array}$ & {$[33,98]$} \\
\hline 8 & MOPECO & $\begin{array}{l}\text { Compatible resolution } \\
\text { with farming } \\
\text { management }\end{array}$ & $\begin{array}{l}\text { Error control } \\
\text { for irrigation } \\
\text { scheduling }\end{array}$ & $\begin{array}{c}\text { Irrigation scheduling } \\
\text { optimization for vegetable } \\
\text { cultivation in Nāgāland, India }\end{array}$ & {$[18,68]$} \\
\hline 9 & CROPWAT & $\begin{array}{l}\text { Sustainable irrigation } \\
\text { effectiveness } \\
\text { management }\end{array}$ & $\begin{array}{l}\text { Risk } \\
\text { management of } \\
\text { water scarcity } \\
\text { in crop } \\
\text { cultivation }\end{array}$ & $\begin{array}{l}\text { Assessment of water } \\
\text { distribution system efficiency } \\
\text { for vegetable irrigation } \\
\text { schedules in Lazio, Italy }\end{array}$ & {$[23,93]$} \\
\hline 10 & MODFLOW & $\begin{array}{l}\text { The generic and } \\
\text { effective water } \\
\text { allocation scheme }\end{array}$ & $\begin{array}{l}\text { Waterdrop } \\
\text { penetration }\end{array}$ & $\begin{array}{l}\text { Estimation of moisture } \\
\text { evapotranspiration for an } \\
\text { apple irrigation system in } \\
\text { Venezuela }\end{array}$ & {$[40,78]$} \\
\hline 11 & PSO-SVM & $\begin{array}{c}\text { Synchronization } \\
\text { between water } \\
\text { allocation and } \\
\text { mechanism adaptation }\end{array}$ & $\begin{array}{l}\text { Stable crop } \\
\text { productivity } \\
\text { and quality } \\
\text { coefficients }\end{array}$ & $\begin{array}{l}\text { Surface irrigation performance } \\
\text { for crop under water scarcity } \\
\text { in Shamaliyah, Saudi Arabia }\end{array}$ & {$[77,91]$} \\
\hline 12 & QUAL2K & $\begin{array}{l}\text { Dynamic decision } \\
\text { variable adjustment for } \\
\text { irrigation system }\end{array}$ & $\begin{array}{l}\text { Infield } \\
\text { infiltration } \\
\text { prediction }\end{array}$ & $\begin{array}{l}\text { Efficiency promotion of water } \\
\text { use system for rice in Kano } \\
\text { river irrigation, Nigeria }\end{array}$ & {$[66,85]$} \\
\hline 13 & NSAE-ANFIS & $\begin{array}{l}\text { Flexibility in water } \\
\text { allocation and } \\
\text { scheduling } \\
\text { implementation }\end{array}$ & $\begin{array}{l}\text { Dynamic } \\
\text { irrigation } \\
\text { process } \\
\text { virtualization }\end{array}$ & $\begin{array}{l}\text { Concentration degree } \\
\text { prediction of drip irrigation } \\
\text { effectiveness for orange } \\
\text { cultivation in } \\
\text { Guangdong, China }\end{array}$ & {$[16,17]$} \\
\hline 14 & DSS-FS & $\begin{array}{l}\text { Optimal production } \\
\text { plan identification }\end{array}$ & $\begin{array}{c}\text { Flexible } \\
\text { irrigation } \\
\text { scheduling and } \\
\text { mechanism } \\
\text { optimization }\end{array}$ & $\begin{array}{l}\text { Optimization of the irrigation } \\
\text { water distribution for cotton } \\
\text { cultivation in Liaoning, China }\end{array}$ & {$[28,66]$} \\
\hline
\end{tabular}

Note: ACO/LIDM, Ant Colony Optimization/Linear Inverted Dumbbell Model; DSSAT, Decision Support System for Agrotechnology Transfer; DSS-FS, Decision Support System-Fertigation Simulator; FAO-AZM, Food and Agriculture Organization-Agroecological Zone Model; NSAE-ANFIS, Normalized Sparse AutoEncoder-Adaptive Neural Fuzzy Inference System; OMI, the Ozone Monitoring Instrument; PSO-SVM, Particle Swarm Optimization-Support Vector Machine; SEBAL, Surface Energy Balance Algorithm for Land; SWAP, Soil, Water, Atmosphere and Plant.

Eventually, according to the latest developments of these theoretical models and irrigation techniques, they could be applied conveniently into different cases of real-life irrigated agriculture, such as the impact evaluation of advanced irrigated agriculture on groundwater-recharge salinity [108,109], performance analysis of irrigated agricultural strategies [110], collaborative management of water resources distribution [111], and quantitative assessment on the water availability for practical irrigated agriculture [112], etc. Although the optimal water allocation policies for sustainable irrigated agriculture are still being studied [113], more endeavours have recently been made in the water-resource management of irrigated agriculture [114,115], risk assessment of drought impacts [116], and environmental irrigation adaption [117], and analyze the effects of urbanization and agricultural activities on groundwater levels and salinity [118]. In their research, Odeh et al. proposed an original conceptual model, which indicated that groundwater and its rate of abstraction is important to supply the increased 
number of inhabitants and their activities. With the help of these novel investigations and practical tests in real-life irrigated agriculture, all the computation models and theoretical methods proposed, including the decision-support systems and mathematical algorithms, which related to water resource allocation and performance management of irrigation systems, could be employed effectively in actual irrigated agriculture, which returns productive profits and facilitates knowledge promotion in precision irrigation cases.

\section{Conclusions}

Precision irrigation represents an important shift in agricultural production. Water allocation mechanism and integrative management effectiveness are representative water theoretical/technical domains that emphasize agricultural irrigation quality. Based on the comprehensive discussions of water allocation mechanism and integrative management effectiveness, we underline several research directions in precision irrigation that could lead to the following new developments:

- $\quad$ Data-oriented irrigation management integrating Artificial Intelligence (AI) functions and big data. Distributed learning could be integrated into a precision irrigation process to increase field productivity and environmental adaptability;

- performance-proven water allocation mechanism capable of constructing accurate and instantaneous irrigation scheduling schemes while guaranteeing a high quality of water resource allocation service;

- cloud-based management systems for precision irrigation, implementing irrigation scheduling and effectiveness prediction for multi-objective service operations by considering environmental information exchanges;

- $\quad$ sustainable precision irrigation able to adaptively control the water consumption and moisture infiltration in the soil field, while fully considering actual integrative management requirements.

Investigating these representative research directions helps to build sustainable, integrative, and evolutionary irrigation systems that could provide the higher quality and efficiency needed for the full application of precision irrigation. We provided a comprehensive outline of the latest research on the collaborative management of irrigation systems, the application characteristics, and the mechanism influences of precision irrigation. This review provides a theoretical and technical reference; the working principles of irrigation water allocation and the inherent mechanism of integrative management were fully revealed and clearly illustrated. Frontier topics such as data-oriented irrigation management, performance-proven water allocation, and cloud-based irrigation control are among the most critical areas to be further explored in the future development of precision irrigation.

\section{Data Availability Statement}

The data that support the findings of this study are available from the corresponding author upon reasonable request.

Author Contributions: Conceptualization, Z.L.; methodology, Z.L.; validation, X.L. and J.X. (Jianbin Xiong); resources, J.X. (Jinrui Xiao). All authors have read and agreed to the published version of the manuscript.

Funding: The author acknowledges funding received from the following science foundations: National Natural Science Foundation of China (51975136, 51575116, U1601204, 52075109), National Key Research and Development Program of China (2018YFB2000501), China National Spark Program (2015GA780065), the Science and Technology Innovative Research Team Program in Higher Educational Universities of Guangdong Province (2017KCXTD025), the Innovative Academic Team Project of Guangzhou Education System (1201610013), the Special Research Projects in the Key Fields of Guangdong Higher Educational Universities (2019KZDZX1009), the Science and Technology Research Project of Guangdong Province (2017A010102014, 2016A010102022), the Science and Technology Research Project of Guangzhou (201707010293), are all appreciated for supporting this work.

Acknowledgments: We thank the editors for their hard work and the referees for their comments and valuable suggestions that helped to improve this paper.

Conflicts of Interest: The authors declare no conflict of interest. 


\section{References}

1. Guo, Z.; Chang, J.; Huang, Q.; Xu, L.; Da, C.; Wu, H. Bi-level optimization allocation model of water resources for different water industries. Water Supply 2013, 14, 470-477. [CrossRef]

2. Peng, J.; Yuan, X.; Qi, L.; Li, Q. A study of multi-objective dynamic water resources allocation modeling of Huai River. Water Supply 2015, 15, 817-824. [CrossRef]

3. Tan, S.; Wu, B.; Yan, N.; Zeng, H. Satellite-based water consumption dynamics monitoring in an extremely arid area. Remote Sens. 2018, 10, 1399. [CrossRef]

4. Daccache, A.; Lamaddalena, N.; Fratino, U. Assessing pressure changes in an on-demand water distribution system on drip irrigation performance-Case study in Italy. J. Irrig. Drain. Eng. 2010, 136, 261-270. [CrossRef]

5. Mohapatra, A.G.; Lenka, S.K.; Keswani, B. Neural network and fuzzy logic based smart DSS model for irrigation notification and control in precision agriculture. Proc. Natl. Acad. Sci. India Sect. A Phys. Sci. 2018, 89, 67-76. [CrossRef]

6. Dai, Z.; Li, Y. A multistage irrigation water allocation model for agricultural land-use planning under uncertainty. Agric. Water Manag. 2013, 129, 69-79. [CrossRef]

7. Muhammad, T.; Naim, H.; Haw, Y.; Nasser, A. Efficiency of a water use system: The case of Kano river irrigation project, Nigeria. Int. J. Civ. Eng. 2018, 16, 929-939.

8. Tsukamoto, Y.; Kitagawa, I.; Nakamura, R. Drainage and irrigation performance of hybrid ditches in converted paddy fields under winter wheat cultivation in Hokkaido. Paddy Water Environ. 2017, 15, 681-691. [CrossRef]

9. Alcon, F.; García-Bastida, P.A.; Soto-García, M.; Martínez-Alvarez, V.; Martin-Gorriz, B.; Baille, A. Explaining the performance of irrigation communities in a water-scarce region. Irrig. Sci. 2017, 35, 193-203. [CrossRef]

10. Aziz, O.; Hussain, S.; Rizwan, M.; Riaz, M.; Bashir, S.; Lin, L.; Mehmood, S.; Imran, M.; Yaseen, R.; Lu, G. Increasing water productivity, nitrogen economy, and grain yield of rice by water saving irrigation and fertilizer-N management. Environ. Sci. Pollut. Res. 2018, 25, 16601-16615. [CrossRef]

11. Sharma, S.P.; Leskovar, D.; Volder, A.; Crosby, K.M.; Ibrahim, A.M.H. Root distribution patterns of reticulatus and inodorus melon (Cucumis melo L.) under subsurface deficit irrigation. Irrig. Sci. 2018, 36, 301-317. [CrossRef]

12. Herrmann, F.; Kunkel, R.; Ostermann, U.; Vereecken, H.; Wendland, F. Projected impact of climate change on irrigation needs and groundwater resources in the metropolitan area of Hamburg (Germany). Environ. Earth Sci. 2016, 75, 1104. [CrossRef]

13. Haj-Amor, Z.; Ritzema, H.; Hashemi, H.; Bouri, S. Surface irrigation performance of date palms under water scarcity in arid irrigated lands. Arab. J. Geosci. 2018, 11, 27. [CrossRef]

14. Mehrabi, F.; Sepaskhah, A.R. Interaction effects of planting method, irrigation regimes, and nitrogen application rates on yield, water and nitrogen use efficiencies of winter wheat (Triticum aestivum). Int. J. Plant Prod. 2018, 12, 265-283. [CrossRef]

15. Fu, Q.; Liu, Y.; Li, T.; Liu, D.; Cui, S. Analysis of irrigation water use efficiency based on the chaos features of a rainfall time series. Water Resour. Manag. 2017, 31, 1961-1973. [CrossRef]

16. Liang, Z.; Liao, S.; Wen, Y.; Liu, X. Working parameter optimization of strengthen waterjet grinding with the orthogonal-experiment-design-based ANFIS. J. Intell. Manuf. 2016, 30, 833-854. [CrossRef]

17. Liang, Z.; Xie, B.; Liao, S.; Zhou, J. Concentration degree prediction of AWJ grinding effectiveness based on turbulence characteristics and the improved ANFIS. Int. J. Adv. Manuf. Technol. 2015, 80, 887-905. [CrossRef]

18. Liu, X.; Liang, Z.; Wen, G.; Yuan, X. Waterjet machining and research developments: A review. Int. J. Adv. Manuf. Technol. 2019, 102, 1257-1335. [CrossRef]

19. Izquiel, A.; Ballesteros, R.; Tarjuelo, J.M.; Moreno, M.A. Optimal reservoir sizing in on-demand irrigation networks: Application to a collective drip irrigation network in Spain. Biosyst. Eng. 2016, 147, 67-80. [CrossRef]

20. Nejadrezaei, N.; Allahyari, M.S.; Sadeghzadeh, M.; Michailidis, A.; El Bilali, H. Factors affecting adoption of pressurized irrigation technology among olive farmers in Northern Iran. Appl. Water Sci. 2018, 8, 190. [CrossRef]

21. Koech, R.; Smith, R.; Gillies, M. Evaluating the performance of a real-time optimisation system for furrow irrigation. Agric. Water Manag. 2014, 142, 77-87. [CrossRef] 
22. Hu, A.; Yu, Z.; Liu, X.; Gao, W.; He, Y.; Li, J. The effects of irrigation and fertilization on the migration and transformation processes of main chemical components in the soil profile. Environ. Geochem. Heal. 2019, 41, 2631-2648. [CrossRef]

23. Yang, G.; Guo, P.; Huo, L.; Ren, C. Optimization of the irrigation water resources for Shijin irrigation district in north China. Agric. Water Manag. 2015, 158, 82-98. [CrossRef]

24. García-Prats, A.; Guillem-Picó, S. Adaptation of pressurized irrigation networks to new strategies of irrigation management: Energy implications of low discharge and pulsed irrigation. Agric. Water Manag. 2016, 169, 52-60. [CrossRef]

25. Jiang, L.; Shang, S.; Yang, Y.; Guan, H. Mapping interannual variability of maize cover in a large irrigation district using a vegetation index-phenological index classifier. Comput. Electron. Agric. 2016, 123, 351-361. [CrossRef]

26. Goldstein, A.; Fink, L.; Meitin, A.; Bohadana, S.; Lutenberg, O.; Ravid, G. Applying machine learning on sensor data for irrigation recommendations: Revealing the agronomist's tacit knowledge. Precis. Agric. 2017, 19, 421-444. [CrossRef]

27. Ganjegunte, G.; Clark, J. Improved irrigation scheduling for freshwater conservation in the desert southwest U.S. Irrig. Sci. 2017, 35, 315-326. [CrossRef]

28. Anwar, A.A.; Ahmad, W.; Bhatti, M.T.; Haq, Z.U. The potential of precision surface irrigation in the Indus Basin Irrigation System. Irrig. Sci. 2016, 34, 379-396. [CrossRef]

29. Carrión, F.; Sanchez-Vizcaino, J.; Corcoles, J.I.; Tarjuelo, J.M.; Moreno, M.A. Optimization of groundwater abstraction system and distribution pipe in pressurized irrigation systems for minimum cost. Irrig. Sci. 2016, 34, 145-159. [CrossRef]

30. Ward, F.A.; Crawford, T.L. Economic performance of irrigation capacity development to adapt to climate in the American Southwest. J. Hydrol. 2016, 540, 757-773. [CrossRef]

31. Li, M.; Guo, P.; Singh, V.P. An efficient irrigation water allocation model under uncertainty. Agric. Syst. 2016, 144, 46-57. [CrossRef]

32. Arora, V.K.; Joshi, R.; Singh, C.B. Irrigation and deep tillage effects on productivity of dry-seeded rice in a subtropical environment. Agric. Res. 2018, 7, 416-423. [CrossRef]

33. Zhao, A. Discussion on the problems and related measures of water-saving irrigation in irrigation and water conservancy project. Constr. Des. Eng. 2018, 8, 125-126. [CrossRef]

34. Ahuja, S.; Khurana, D.S.; Singh, K. Soil matric potential-based irrigation scheduling to potato in the northwestern indian plains. Agric. Res. 2018, 8, 320-330. [CrossRef]

35. Ragab, M.F.S.; Shimizu, K.; El Hassan, W.H.A.; Nakumura, K.; Watanabe, T. Investigation of irrigation performance at the tertiary canal level in the Nile Delta of Egypt. Paddy Water Environ. 2019, 17, 69-74. [CrossRef]

36. Zhang, J.; Lin, X.; Guo, B. Multivariate copula-based joint probability distribution of water supply and demand in irrigation district. Water Resour. Manag. 2016, 30, 2361-2375. [CrossRef]

37. Massey, J.H.; Stiles, C.M.; Epting, J.W.; Powers, R.S.; Kelly, D.B.; Bowling, T.H.; Janes, C.L.; Pennington, D.A. Long-term measurements of agronomic crop irrigation made in the Mississippi delta portion of the lower Mississippi River Valley. Irrig. Sci. 2017, 35, 297-313. [CrossRef]

38. Brinkhoff, J.; Hornbuckle, J.; Barton, J.L. Assessment of aquatic weed in irrigation channels using UAV and satellite imagery. Water 2018, 10, 1497. [CrossRef]

39. Ayyad, S.; Al Zayed, I.S.; Ha, V.T.T.; Ribbe, L. The performance of satellite-based actual evapotranspiration products and the assessment of irrigation efficiency in Egypt. Water 2019, 11, 1913. [CrossRef]

40. Trezza, R.; Sánchez, L. Estimation of spatially-distributed crop evapotranspiration using satellite images for the "Cenizo" irrigation system in Venezuela. Rev. Fac. Agron. 2014, 31, 566-576.

41. Serra, P.; Pons, X. Two Mediterranean irrigation communities in front of water scarcity: A comparison using satellite image time series. J. Arid. Environ. 2013, 98, 41-51. [CrossRef]

42. Zhang, W.; Zhang, Z.; Huang, Z. Auto-extraction method of farmland irrigation and drainage system based on domestic high-resolution satellite images. In Proceedings of the 2016 Fifth International Conference on Agro-Geoinformatics (Agro-Geoinformatics), Institute of Electrical and Electronics Engineers (IEEE), Tianjin, China, 18-20 July 2016; pp. 1-6. [CrossRef]

43. Zhang, X.; Qiu, J.; Leng, G.; Yang, Y.; Gao, Q.; Fan, Y.; Luo, J. The potential utility of satellite soil moisture retrievals for detecting irrigation patterns in China. Water 2018, 10, 1505. [CrossRef] 
44. Karimi, P.; Bongani, B.; Blatchford, M.; De Fraiture, C. Global satellite-based ET products for the local level irrigation management: An application of irrigation performance assessment in the Sugarbelt of Swaziland. Remote Sens. 2019, 11, 705. [CrossRef]

45. Ghebreamlak, A.Z.; Tanakamaru, H.; Tada, A.; Adam, B.M.A.; Elamin, K.A.E. Satellite-based mapping of cultivated area in Gash Delta Spate irrigation system, Sudan. Remote Sens. 2018, 10, 186. [CrossRef]

46. Veysi, S.; Naseri, A.A.; Hamzeh, S.; Bartholomeus, H. A satellite based crop water stress index for irrigation scheduling in sugarcane fields. Agric. Water Manag. 2017, 189, 70-86. [CrossRef]

47. Taherparvar, M.; Pirmoradian, N. Estimation of Rice Evapotranspiration using reflective images of landsat satellite in Sefidrood irrigation and Drainage network. Rice Sci. 2018, 25, 111-116. [CrossRef]

48. Fontanet, M.; Fernàndez-Garcia, D.; Ferrer, F. The value of satellite remote sensing soil moisture data and the DISPATCH algorithm in irrigation fields. Hydrol. Earth Syst. Sci. 2018, 22, 5889-5900. [CrossRef]

49. Pramudya, Y.; Komariah; Dewi, W.S.; Sumani; Mujiyo; Sukoco, T.A.; Rozaki, Z. Remote sensing for estimating agricultural land use change as the impact of climate change. In Proceedings of the SPIE Asia-Pacific Remote Sensing. Land Surface and Cryosphere Remote Sensing III, New Delhi, India, 5 May 2016; Volume 9877, p. 987720. [CrossRef]

50. Vorovencii, I. Assessing and monitoring the risk of land degradation in Baragan Plain, Romania, using spectral mixture analysis and Landsat imagery. Environ. Monit. Assess. 2016, 188, 439. [CrossRef]

51. Zhisen, C.; Bingcheng, S.I. Monitoring cropland types at village-town scale in Hetao irrigation district using high-resolution satellite images. J. Irrig. Drain. 2018, 37, 124-128.

52. Piedelobo, L.; Ortega-Terol, D.; Del Pozo, S.; Hernández-López, D.; Ballesteros, R.; Moreno, M.A.; Molina, J.-L.; González-Aguilera, D. HidroMap: A new tool for irrigation monitoring and management using free satellite imagery. ISPRS Int. J. Geo-Inf. 2018, 7, 220. [CrossRef]

53. Saraiva, M.M.; Protas, E.; Salgado, M.P.G.; Souza, C.; Souza, J.C.M. Automatic mapping of center pivot irrigation systems from satellite images using deep learning. Remote Sens. 2020, 12, 558. [CrossRef]

54. Corbari, C.; Salerno, R.; Ceppi, A.; Telesca, V.; Mancini, M. Smart irrigation forecast using satellite LANDSAT data and meteo-hydrological modeling. Agric. Water Manag. 2019, 212, 283-294. [CrossRef]

55. Mokhtari, A.; Noory, H.; Vazifedoust, M.; Bahrami, M. Estimating net irrigation requirement of winter wheat using model- and satellite-based single and basal crop coefficients. Agric. Water Manag. 2018, 208, 95-106. [CrossRef]

56. Knipper, K.R.; Kustas, W.P.; Anderson, M.C.; Alfieri, J.G.; Prueger, J.H.; Hain, C.R.; Gao, F.; Yang, Y.; McKee, L.G.; Nieto, H.; et al. Evapotranspiration estimates derived using thermal-based satellite remote sensing and data fusion for irrigation management in California vineyards. Irrig. Sci. 2018, 37, 431-449. [CrossRef]

57. Islam, S.; Talukdar, B. A linked simulation-optimization (LSO) model for conjunctive irrigation management using clonal selection algorithm. J. Inst. Eng. (India) Ser. A 2016, 97, 181-189. [CrossRef]

58. Ghumman, A.R.; Ahmad, S.; Rahman, S.; Khan, Z. Investigating management of irrigation water in the upstream control system of the upper swat canal. Iran. J. Sci. Technol. Trans. Civ. Eng. 2018, 42, 153-164. [CrossRef]

59. Moghimi, M.M.; Sepaskhah, A.R. Effect of various on-farm water management scenarios on equity and productivity in irrigation networks. Water Resour. Manag. 2016, 30, 2405-2424. [CrossRef]

60. Levin, A.G.; Peres, M.; Noy, M.; Love, C.; Gal, Y.; Naor, A. The response of field-grown mango (cv. Keitt) trees to regulated deficit irrigation at three phenological stages. Irrig. Sci. 2018, 36, 25-35. [CrossRef]

61. Trifonov, P.; Lazarovitch, N.; Arye, G. Increasing water productivity in arid regions using low-discharge drip irrigation: A case study on potato growth. Irrig. Sci. 2017, 35, 287-295. [CrossRef]

62. Liu, H.; Gao, Y.; Sun, J.; Wu, X.; Jha, S.K.; Zhang, H.; Gong, X.; Li, Y. Responses of yield, water use efficiency and quality of short-season cotton to irrigation management: Interactive effects of irrigation methods and deficit irrigation. Irrig. Sci. 2016, 35, 125-139. [CrossRef]

63. Mangalassery, S.; Rejani, R.; Singh, V.; Adiga, J.D.; Kalaivanan, D.; Rupa, T.R.; Philip, P.S. Impact of different irrigation regimes under varied planting density on growth, yield and economic return of cashew (Anacardium occidentale L.). Irrig. Sci. 2019, 37, 483-494. [CrossRef]

64. Goldhamer, D.A.; Fereres, E. Establishing an almond water production function for California using long-term yield response to variable irrigation. Irrig. Sci. 2016, 35, 169-179. [CrossRef] 
65. Zema, D.A.; Nicotra, A.; Zimbone, S.M. Improving management scenarios of water delivery service in collective irrigation systems: A case study in Southern Italy. Irrig. Sci. 2018, 37, 79-94. [CrossRef]

66. Vivas, G.; Giráldez, J.V.; Mateos, L. Water management in an ancestral irrigation system in southern Spain: A simulation analysis. Irrig. Sci. 2016, 34, 343-360. [CrossRef]

67. Morshed, M.; Islam, T.; Jamil, R. Soil salinity detection from satellite image analysis: An integrated approach of salinity indices and field data. Environ. Monit. Assess. 2016, 188, 1-10. [CrossRef]

68. Li, F.; Yu, N.; Zhao, Y. Irrigation scheduling optimization for cotton based on the AquaCrop model. Water Resour. Manag. 2018, 33, 39-55. [CrossRef]

69. Navarro-Hellín, H.; Del Rincon, J.M.; Domingo-Miguel, R.; Soto, F.; Torres, R. A decision support system for managing irrigation in agriculture. Comput. Electron. Agric. 2016, 124, 121-131. [CrossRef]

70. Navarro-Hellín, H.; Torres, R.; Soto, F.; Albaladejo-Pérez, C.; López-Riquelme, J.; Domingo-Miguel, R. A wireless sensors architecture for efficient irrigation water management. Agric. Water Manag. 2015, 151, 64-74. [CrossRef]

71. Wu, S.-J.; Chiueh, Y.-W.; Hsu, C.-T. Modeling risk analysis for rice production due to agro-climate change and uncertainty in irrigation water. Paddy Water Environ. 2017, 16, 35-53. [CrossRef]

72. Singh, A.K.; Kumari, V.V.; Gupta, R.; Singh, P.; Solomon, S. Efficient irrigation water management in sugarcane through alteration of field application parameters under subtropical India. Sugar Tech 2017, 20, 21-28. [CrossRef]

73. Barzegari, M.; Sepaskhah, A.R.; Ahmadi, S.H. Irrigation and nitrogen managements affect nitrogen leaching and root yield of sugar beet. Nutr. Cycl. Agroecosyst. 2017, 108, 211-230. [CrossRef]

74. Faria, L.C.; Nörenberg, B.G.; Colombo, A.; Dukes, M.; Timm, L.C.; Beskow, S.; Caldeira, T.L. Irrigation distribution uniformity analysis on a lateral-move irrigation system. Irrig. Sci. 2019, 37, 195-206. [CrossRef]

75. Maier, N.; Dietrich, J. Using SWAT for strategic planning of basin scale irrigation control policies: A case study from a humid region in Northern Germany. Water Resour. Manag. 2016, 30, 3285-3298. [CrossRef]

76. Alghory, A.; Yazar, A. Evaluation of crop water stress index and leaf water potential for deficit irrigation management of sprinkler-irrigated wheat. Irrig. Sci. 2018, 37, 61-77. [CrossRef]

77. Cheong, R.N.; Teeluck, M. Development of an irrigation scheduling software for sugarcane. Sugar Tech 2017, 20, 36-39. [CrossRef]

78. Stoochnoff, J.A.; Graham, T.; Dixon, M.A. Drip irrigation scheduling for container grown trees based on plant water status. Irrig. Sci. 2018, 36, 179-186. [CrossRef]

79. Liang, Z.; Liu, X.; Xiao, J.; Liu, C. Adaptive prediction of abrasive impacting pressure effectiveness in strengthen jet grinding using NSAE-ANFIS. Int. J. Adv. Manuf. Technol. 2020, 106, 2805-2828. [CrossRef]

80. Liang, Z.; Shan, S.; Liu, X.; Wen, Y. Fuzzy prediction of AWJ turbulence characteristics by using typical multi-phase flow models. Eng. Appl. Comput. Fluid Mech. 2017, 11, 225-257. [CrossRef]

81. Liang, Z.; Liu, X.; Wen, G.; Yuan, X. Influence analysis of sprinkler irrigation effectiveness using ANFIS. Int. J. Agric. Biol. Eng. 2019, 12, 135-148. [CrossRef]

82. Liang, Z.; Liu, X.; Wen, G.; Xiao, J. Effectiveness prediction of abrasive jetting stream of accelerator tank using normalized sparse autoencoder-adaptive neural fuzzy inference system. Proc. Inst. Mech. Eng. Part B: J. Eng. Manuf. 2020, 234, 1615-1639. [CrossRef]

83. Opan, M. Irrigation-energy management using a DPSA-based optimization model in the Ceyhan Basin of Turkey. J. Hydrol. 2010, 385, 353-360. [CrossRef]

84. Mabaya, G.; Unami, K.; Fujihara, M. Stochastic optimal control of agrochemical pollutant loads in reservoirs for irrigation. J. Clean. Prod. 2017, 146, 37-46. [CrossRef]

85. Barradas, J.M.; Matula, S.; Doležal, F. A Decision support System-Fertigation Simulator (DSS-FS) for design and optimization of sprinkler and drip irrigation systems. Comput. Electron. Agric. 2012, 86, 111-119. [CrossRef]

86. Delgoda, D.; Malano, H.; Saleem, S.K.; Halgamuge, M.N. Irrigation control based on model predictive control (MPC): Formulation of theory and validation using weather forecast data and AQUACROP model. Environ. Model. Softw. 2016, 78, 40-53. [CrossRef]

87. García-Vila, M.; Fereres, E. Combining the simulation crop model AquaCrop with an economic model for the optimization of irrigation management at farm level. Eur. J. Agron. 2012, 36, 21-31. [CrossRef] 
88. Pramanik, M.; Garg, N.K.; Tripathi, S.K.; Singh, R.; Ranjan, R. A new approach of canopy temperature based irrigation scheduling of wheat in humid subtropical climate of India. Proc. Natl. Acad. Sci. India Sect. B Boil. Sci. 2016, 87, 1261-1269. [CrossRef]

89. Kovacs, K.; Mancini, M.; West, G.H. Landscape irrigation management for maintaining an aquifer and economic returns. J. Environ. Manag. 2015, 160, 271-282. [CrossRef]

90. Tsakmakis, I.; Kokkos, N.; Pisinaras, V.; Papaevangelou, V.; Hatzigiannakis, E.; Arampatzis, G.; Gikas, G.; Linker, R.; Zoras, S.; Evagelopoulos, V.; et al. Operational precise irrigation for cotton cultivation through the coupling of meteorological and crop growth models. Water Resour. Manag. 2016, 31, 563-580. [CrossRef]

91. Awan, U.K.; Ibrakhimov, M.; Benli, B.; Lamers, J.P.A.; Sahi, Q.-U.-A. A new concept of irrigation response units for effective management of surface and groundwater resources: A case study from the multi-country Fergana Valley, Central Asia. Irrig. Sci. 2016, 35, 55-68. [CrossRef]

92. Khadra, R.; Moreno, M.A.; Awada, H.; Lamaddalena, N. Energy and hydraulic performance-based management of large-scale pressurized irrigation systems. Water Resour. Manag. 2016, 30, 3493-3506. [CrossRef]

93. Saavoss, M.; Majsztrik, J.; Belayneh, B.; Lea-Cox, J.; Lichtenberg, E. Yield, quality and profitability of sensor-controlled irrigation: A case study of snapdragon (Antirrhinum majus L.) production. Irrig. Sci. 2016, 34, 409-420. [CrossRef]

94. Exposito, A.; Berbel, J. Why is water pricing ineffective for deficit irrigation schemes? A case study in southern Spain. Water Resour. Manag. 2016, 31, 1047-1059. [CrossRef]

95. Lu, W.; Cheng, W.; Zhang, Z.; Xin, X.; Wang, X. Differences in rice water consumption and yield under four irrigation schedules in central Jilin Province, China. Paddy Water Environ. 2015, 14, 473-480. [CrossRef]

96. Saini, K.S.; Brar, N.S. Crop and water productivity of sugarbeet (Beta vulgaris) under different planting methods and irrigation schedules. Agric. Res. 2018, 7, 93-97. [CrossRef]

97. Chenafi, A.; Philippe, M.; Ferreira, M.I.; Houria, C.; Chaves, M.M.; Christoph, C. Scheduling deficit subsurface drip irrigation of apple trees for optimizing water use. Arab. J. Geosci. 2019, 12, 74. [CrossRef]

98. Laurenson, S.; Cichota, R.; Reese, P.; Breneger, S. Irrigation runoff from a rolling landscape with slowly permeable subsoils in New Zealand. Irrig. Sci. 2018, 36, 121-131. [CrossRef]

99. Pan, H.; Xu, Q. Quantitative analysis on the influence factors of the sustainable water resource management performance in irrigation areas: An empirical research from China. Sustainability 2018, 10, 264. [CrossRef]

100. Rougé, C.; Tilmant, A.; Zaitchik, B.; Dezfuli, A.; Salman, M. Identifying key water resource vulnerabilities in data-scarce transboundary river basins. Water Resour. Res. 2018, 54, 5264-5281. [CrossRef]

101. Ren, Y.; Wei, S.; Cheng, K.; Fu, Q. Valuation and pricing of agricultural irrigation water based on macro and micro scales. Water 2018, 10, 1044. [CrossRef]

102. Shindo, S.; Yamamoto, K. Strengthening water users' organization targeting for participatory irrigation management in Egypt. Paddy Water Environ. 2017, 15, 773-785. [CrossRef]

103. Wheeler, S.A.; Carmody, E.; Grafton, R.; Kingsford, R.; Zuo, A. The rebound effect on water extraction from subsidising irrigation infrastructure in Australia. Resour. Conserv. Recycl. 2020, 159, 104755. [CrossRef]

104. Wang, Y.; Huang, J.; Wang, J.; Findlay, C. Mitigating rice production risks from drought through improving irrigation infrastructure and management in China. Aust. J. Agric. Resour. Econ. 2017, 62, 161-176. [CrossRef]

105. Watts, R.J.; Kopf, R.K.; McCasker, N.; Howitt, J.A.; Conallin, J.; Wooden, I.; Baumgartner, L.J. Adaptive management of environmental flows: Using irrigation infrastructure to deliver environmental benefits during a large hypoxic blackwater event in the Southern Murray-Darling Basin, Australia. Environ. Manag. 2017, 61, 469-480. [CrossRef]

106. Suhardiman, D. Irrigation management transfer and the shaping of irrigation realities in Indonesia: From means to empower farmers to a tool to transfer rent seeking? Hum. Organ. 2016, 75, 326-335. [CrossRef]

107. Paranage, K. Understanding the relationship between water infrastructure and socio-political configurations: A case study from Sri Lanka. Water 2018, 10, 1402. [CrossRef]

108. Foster, S.; Bosch, A.P.; Vallejos, Á.; Molina, L.; Llop, A.; Macdonald, A.M. Impact of irrigated agriculture on groundwater-recharge salinity: A major sustainability concern in semi-arid regions. Hydrogeol. J. 2018, 26, 2781-2791. [CrossRef] 
109. Digna, R.F.; Mohamed, Y.A.; Van Der Zaag, P.; Uhlenbrook, S.; Van Der Krogt, W.; Corzo, G. Impact of water resources development on water availability for hydropower production and irrigated agriculture of the Eastern Nile Basin. J. Water Resour. Plan. Manag. 2018, 144, 05018007. [CrossRef]

110. Harmanny, K.S.; Malek, Ž. Adaptations in irrigated agriculture in the Mediterranean region: An overview and spatial analysis of implemented strategies. Reg. Environ. Chang. 2019, 19, 1401-1416. [CrossRef]

111. Ajay, S. Assessment of different strategies for managing the water resources problems of irrigated agriculture. Agr. Water Manag. 2018, 208, 187-192. [CrossRef]

112. Zaki, N.A.; Haghighi, A.T.; Rossi, P.M.; Xenarios, S.; Kløve, B. An index-based approach to assess the water availability for irrigated agriculture in Sub-Saharan Africa. Water 2018, 10, 896. [CrossRef]

113. Das, B.; Singh, A.; Panda, S.N.; Yasuda, H. Optimal land and water resources allocation policies for sustainable irrigated agriculture. Land Use Policy 2015, 42, 527-537. [CrossRef]

114. Chukalla, A.D.; Krol, M.S.; Hoekstra, A.Y. Marginal cost curves for water footprint reduction in irrigated agriculture: Guiding a cost-effective reduction of crop water consumption to a permit or benchmark level. Hydrol. Earth Syst. Sci. 2017, 21, 3507-3524. [CrossRef]

115. Singh, A. Review: Computer-based models for managing the water-resource problems of irrigated agriculture. Hydrogeol. J. 2015, 23, 1217-1227. [CrossRef]

116. Lopez-Nicolas, A.; Pulido-Velazquez, M.; Macian-Sorribes, H. Economic risk assessment of drought impacts on irrigated agriculture. J. Hydrol. 2017, 550, 580-589. [CrossRef]

117. Lauren, H.; Christopher, A.S. Drought adaptation and development: Small-scale irrigated agriculture in northeast Brazil. Clim. Develop. 2018, 10, 337-346. [CrossRef]

118. Odeh, T.; Mohammad, A.H.; Hussein, H.; Ismail, M.; Almomani, T. Over-pumping of groundwater in Irbid governorate, northern Jordan: A conceptual model to analyze the effects of urbanization and agricultural activities on groundwater levels and salinity. Environ. Earth Sci. 2019, 78, 40. [CrossRef]

Publisher's Note: MDPI stays neutral with regard to jurisdictional claims in published maps and institutional affiliations.

(C) 2020 by the authors. Licensee MDPI, Basel, Switzerland. This article is an open access article distributed under the terms and conditions of the Creative Commons Attribution (CC BY) license (http://creativecommons.org/licenses/by/4.0/). 